Article

\title{
Sergei and the "Divinely Appointed" Stalin: Theology and Ecclesiology in Church-State Relations in the Soviet Union in the Lead-up to the Cold War
}

\author{
Roland Boer ${ }^{1,2}$ \\ 1 School of Humanities and Social Science, The University of Newcastle, Callaghan NSW 2308, Australia; \\ Roland.Boer@newcastle.edu.au \\ 2 School of Liberal Arts, Renmin University of China, 59 Zhongguancun Street, Beijing 100872, China; \\ Roland.Boer@newcastle.edu.au
}

Received: 2 March 2018; Accepted: 12 April 2018; Published: 16 April 2018

\begin{abstract}
In contrast to the tendency to focus on political and social reasons for the rapprochement between the Soviet government and the Russian Orthodox Church, between Stalin and the later patriarch Sergei, this article deals with theological and ecclesiological sensibilities. One would expect such reasons from the side of the church but I also argue that they were important for Stalin's considerations and acts. His deep awareness and intimate knowledge of the church, and active involvement and concrete proposals in the long interaction between church and state, were as important as those of Sergei. The article begins with a reconsideration of Stalin's period of theological study, which influenced him deeply and provided with him unique insights into the nature of the church. After this period, an intriguing path unfolds, through key categories of Stalin's thought thought and his effort-which was strongly opposed-to include the article on religious freedom in the 1936 constitution, let alone the definition of socialism (in contrast to communism) in terms of two biblical verses in the very same constitution. At the same time, the statements and actions of Sergei, already from 1927, were also part of the narrative, so the analysis moves between church and state until the meeting in 1943. All of this is crucial material for understanding developments in the period officially known as the Cold War.
\end{abstract}

Keywords: Stalin; Sergei; theology; ecclesiology; church-state relations; rapprochement; concordat

\section{Introduction}

Very late on the fourth day of September 1943, the patriarchal locum tenens of the Russian Orthodox Church, Sergei, met with Joseph Stalin. The outcome was a historic informal concordat between the Soviet government and church, with the church leadership and administrative structures re-established, theological colleges, monasteries and thousands of places of worship reopened and imprisoned clergy released. Even more, the government actively fostered internationally the extension of the church's canonical jurisdiction and administrative authority beyond what it had been before 1917. What did the Russian government obtain in response? More immediately, the church continued to give theological, moral and material support for the Great Patriotic War, the tide of which had turned in favour of the Red Army. In the long term, the church now had official government structures for its affairs in the shape of the Council for the Affairs of the Russian Orthodox Church (CAROC), confirmation of the winding back of anti-religious activities and its recovery was assured.

Interpretations of these events vary. At times, it is cast in terms of a crafty politician seeking crucial domestic and international support during a time of crisis and then using the church as an instrument of Soviet expansion, aided by "collaborationist" clergy seeking to work with a "dictator" in the name of Russian nationalism and for its own earthly ends (Solzhenitsyn 1972, p. 6; 1974, p. 17; 
Dunlop 1983, pp. 14-16; Volkogonov 1990, pp. 382-83; Walicki 1995, p. 444; Roccucci 2009; Reese 2014). Others-more sympathetic to the church-frame the developments in terms of a struggle between an (ancient) church and an atheistic state (Pospielovsky 1984; Walters 1986; Shkarovskii 1999), with the consequent "secularisation" of the church (Oboznij 2017). More helpfully, a number of studies have stressed the cooperative incentives from both sides, although they tend to focus on political and social considerations (Fletcher 1973; Pospielovsky 1997; Dickinson 2000; Chumachenko 2002¹).

By contrast, I propose another dimension: the actions and statements of both Stalin and Sergei evince theological awareness and ecclesiological sensibilities. One would expect that the church had significant, if not primary, theological and ecclesiological incentives—as Odintsov (1994b, 1995) and Kalkandjieva (2015) show very well. But Stalin? It turns out that Stalin's own interest was far more than political. His deep awareness and intimate knowledge of the church and active involvement and concrete proposals in the long interaction between church and state, were as important as those of Sergei. While the actions of Sergei and the church have been studied in some detail, less attention has been devoted to what may be called Stalin's theological and ecclesiological involvement. Thus, the following analysis begins with a reconsideration of Stalin's period of theological study, which influenced him deeply and provided with him unique insights into the very nature of the church. After this period, I trace an intriguing path, through key categories of thought and his effort-which was strongly opposed-to include the article on religious freedom in the 1936 constitution, let alone the definition of socialism (in contrast to communism) in terms of two biblical verses in the very same constitution. At the same time, the statements and actions of Sergei, already from 1927, were also part of the narrative, so my analysis moves between church and state until the meeting in 1943.

A few comments on what this study is not are in order. To begin with, it is not a study of the Cold War period per se but rather of an important part of the lead-up to this period. The material with which I deal is crucial for framing the later Cold War standoff over religion and the church. Further, this is not a study in "psychohistory", seeking elusive motivations from scraps of information here and there. The more usual types of "psychohistory" attempt to espy the making of a tyrant in the experiences of the young Stalin-whether a strict regime at the theological college or an abusive father or corporal punishment at the hands of his parents (Tucker 1973; Rancour-Laferriere 1988; Kun 2003; Shakhireva 2007). Suny (1991) has warned against the dangers of this approach, we still find broader efforts to identify "motivations" for actions. The archives are a favourite location for such searches but they face insurmountable problems on this matter. Psychological motivations are notoriously difficult to discern. Even if we were able to interview the participants directly, this would by no means establish motivations, of which the most powerful are subconscious. For this reason, I deal with events, statements and actions. In order to understand the developments, I propose a hypothesis that may make some more sense of how and why the concordat happened. But it remains a hypothesis that may be more or less persuasive, depending on the reader's prior assumptions and perspectives.

\section{Theological Student}

The account begins with an experience unique to a world communist leader: Stalin's theological study for five years (1894-1899) at the Tiflis (Tbilisi in Georgian) Spiritual Seminary, a training college for priests in the Russian Orthodox Church. As one of the highest educational institutions in Georgia—alongside the more "secular" gymnasia—the college took in mostly Georgian students from across class backgrounds, from sons of church leaders to poor students needing scholarships. The aim was to take the best and brightest young men and train them for the priesthood, university study and even the civil service- the roles were closely connected. The college had its negative and positive aspects, at least from the perspective of the students. On the negative side, this meant speaking

1 The work by Chumachenko is a translation of her earlier Russian text (Chumachenko 1999). 
and writing only in Russian, even in private, and not in the native Georgian of so many of the students-although by 1895 some concession was made, with courses in Georgian literature and history. The church hierarchy in the seminary was decidedly reactionary, seeking to instil reverence for the tsar and God, in equal measure. Discipline was tight, with the whole day carefully organised: bells rung for waking, prayers, meals, classes and lights out. ${ }^{2}$ Outside excursions were limited, random checks were made to ensure the teenage boys were not engaged in any nefarious activities, ${ }^{3}$ and reading was heavily censored. Textbooks and the Bible were standard fare, the students wore cassocks and the weekends were given over to prayer and liturgy in the college chapel. On the positive side, the young man with the biblical name of Joseph (given to him at his baptism by his godfather, Father Mikhail Tsikhitatrishvili (Kun 2003, p. 8)) experienced-for the era-an exceptionally thorough theological education. And he came to appreciate the ascetic life of a theological student, with its simple diet of bread and beans and the ability to get by with little.

But before we consider in a little more detail what he studied and how he fared, let us backtrack for a moment, for this was not Stalin's first encounter with a church institution. He had already spent almost six years, from 1888 to 1894, at the parish school of his home town, Gori. This was a Russian language school, normally taking seven years, ${ }^{4}$ with four basic and three preliminary grades. The three grades were themselves divided into lower, medium and upper, where Russian was the focus. Kun (2003, p. 13) observes that the school had "surprisingly well-trained pedagogues"—surprising, perhaps, given that Gori was not a large centre. They were nearly all tertiary trained, whether in university or theological college, and languages at the school included-apart from Russian-Church Slavonic and Greek.

The experience not only provided Stalin with his social network but also set him on the path to the priesthood. This calling was the fervent wish of his (literate) mother, who had prayed and cared for her only son (two earlier sons had died) through a range of childhood mishaps and diseases, including scarlet fever and smallpox. ${ }^{5}$ Despite the challenges, or perhaps because of them, Stalin did well indeed at the Gori Church School. The curriculum was notably theological, with sacred history, Orthodox catechism, liturgical exegesis and ecclesiastical Typikon, Greek, Russian and Church Slavonic, Georgian, geography, arithmetic, handwriting and liturgical chant (Khlevniuk 2015, p. 14). The school reports at the end of his time in Gori give him an "excellent" for conduct and the top marks of "excellent" (5) for all subjects, except Greek and arithmetic, for which he received "very good" (4). He was clearly an "outstanding pupil" (Kun 2003, p. 14), at the top of his final year. He also impressed with his devoutness, attending all church services, reading the liturgy and leading the choir singing. A fellow student recalled many years later: "I remember that he not only performed the religious rites but also always reminded us of their significance" (quoted in (Service 2004, p. 28)). The school awarded him a copy of the biblical Book of Psalms, with the inscription, "To Iosif Jughashvili ... for excellent progress, behaviour and excellent recitation of the Psalter" (Kotkin 2014, p. 20). As a result, the teaching staff at the school recommended-unanimously - that he take up further studies at the theological college in Tiflis, subject to success in the entrance examination.

2 As one of Stalin's classmates recalled: "We were brought to a four-story building and put in huge dormitory rooms with 20-30 people each ... Life in the theological seminary was repetitious and monotonous. We arose at seven in the morning. First, we were forced to pray, then we had tea, and after the bell we went to class ... Classes continued, with breaks, until two o'clock. At three we had supper. At five there was roll call, after which we were not allowed to leave the building. We felt as if we were in prison. We were again taken to vespers, and at eight we had tea and then each class went to its own room to do assignments and at ten it was lights out, sleep" (quoted in Khlevniuk 2015, p. 16).

3 In an intriguing interview with Emil Ludwig in 1931, Stalin recalled: "At nine o'clock the bell rings for morning tea, we go to the dining-room and when we return to our rooms we find that meantime a search has been made and all our chests have been ransacked" (Stalin 1954, p. 116; Stalin 1951, p. 114).

4 Stalin had skipped the preliminary year due to his prior study of Russian.

5 Stalin's later observation to Emil Ludwig should be given its due: "My parents were uneducated but they did not treat me badly by any means [no obrashchalis' oni so mnoŭ sovsem ne plokho]" (Stalin 1954, p. 115; Stalin 1951, p. 113). 
At the age of 15, in September 1894, Stalin arrived in the Georgian capital to begin the next stage of his study. Let us return to that institution and see what he and his fellow students studied. The earlier years included both "secular" and theological subjects: Russian philology and literature; secular history; mathematics; Latin; Greek; Church Slavonic singing; Georgian Imeretian singing; biblical studies. By the final years, the subjects became more theological: ecclesiastical history; liturgics; homiletics; comparative theology; moral theology; practical pastoral work; didactics; church history; church singing; various aspects of biblical studies. Some subjects may have changed but throughout the Bible and church singing were constants. The young Stalin was noted by his teachers for his phenomenal memory, subtle intellect and voracious reading (albeit not always of the proscribed variety). His marks varied over the years, ranging from high to low, especially from the middle years onwards when he became more involved with revolutionary groups. However, he was far from a "drop-out", as the "copy of the final certificate" - which Stalin requested four months after he left the college-indicates (Kun 2003, pp. 31-32):

Iosif Dzhugashvili, student at the Tiflis Theological Seminary, the son of Vissarion, a peasant living in the town of Gori in the province of Tiflis, who was born on the sixth day of December in the year 1878, having completed the course of studies at the Gori Church School was admitted to the Tiflis Theological Seminary in the month of September 1894. He studied at the aforesaid institution until the twenty-ninth day of May 1899, and in addition to excellent conduct (5) he achieved the following results:

Exegesis of the Holy Script—very good (4)

History of the Bible—very good (4)

Ecclesiastical history-good (3)

Homiletics—good (3)

Liturgics

Russian literature-very good (4)

History of Russian literature-very good (4)

Universal secular history—very good (4)

Russian secular history—very good (4)

Algebra-very good (4)

Geometry-very good (4)

Easter liturgy—very good (4)

Physics—very good (4)

Logic—outstanding (5)

Psychology—very good (4)

Ecclesiastical Georgian subjects—very good (4)

Greek language-very good (4)

Latin language - not studied

Ecclesiastical singing: Slavic—outstanding (5)

in Georgian language—very good (4).

While not at the peak of academic achievements, these results are hardly cause for shame. More significantly for my purposes, Stalin had become thoroughly versed in theological matters. He knew the history of the church back to front; he could sing very well indeed (his tenor was a core of the chapel choir); he read Greek; and he knew intimately how the church itself worked. Above all, he knew the intricacies of theology and the Bible. More than a decade of training in such subjects, let alone periods of diligent study and achievement, were bound to leave their impression on a young man. 
It is beyond my remit to deal at length with the much-discussed reasons why Stalin left the theological college not long before the final examinations. Yes, he was involved in "subversive" activities and was disciplined reasonably often but so were other students. Yet, unlike many before him, none of these activities were enough to expel Stalin. Was he less of a radical than those who were expelled? Did he manage to conceal his activities more successfully? In fact, the type of behaviour Stalin exhibited was not far from what one might expect from a teenage boy at a strict theological college in the late nineteenth century. Strictness was the norm, with liberal doses of corporal punishment and confinement. But so was student rebelliousness. The teaching staff, for all their failings, were quite familiar with the antics of young men like Stalin.

Stalin was not expelled: he left the seminary shortly before sitting for the final examinations in May of 1899, which would have qualified him to become a priest in the Russian Orthodox Church, if not to proceed to university. Many are the suggestions as to why he did so: he was "kicked out" because of revolutionary activity (Khlevniuk 2015, p. 20); his mother had kept him home for medical reasons (Kun 2003, p. 35); he was unable to afford the fees, or the excuse of fees was used by the college to get rid of a troublesome student (Kotkin 2014, p. 36). However, a hint may be found in the patience of the college rectorate, especially in light of Stalin's generally good results. They suggested that he take some time away, perhaps in a temporary church post or in a lower level teaching position. Notably, they did not pursue him for the outstanding fees, an astronomical amount of more than 600 roubles, for not continuing to work in the church or at least become a teacher. The leaders may well have been in a similar position at some time themselves, for it would not be the first occasion that a rebellious young man had made his way to the priesthood and church leadership -in fact, it was often seen as a prerequisite for the priesthood. Time would shape him, they felt. Stalin was not to be swayed. He did not return to the college after the Easter break at home in Gori, unable for personal reasons to take the final step and sit the examinations. In the end, the reason seems to have been existential: the life of a priest was not for him, so he chose to leave. A big decision, obviously, but it would not be the first time someone training for the church has decided to leave for another life. For anyone who has experienced such a profound shift, the decision is life-changing but also liberating.

To the end of her life in 1937, Stalin's devout mother-Ekatarine (Ketevan) Geladze-lamented the fact that Stalin had not become a priest, if not rising higher in the church hierarchy. No matter whether he was the preeminent leader of the USSR, the largest country in the world; no matter that he had driven through the program of the socialist offensive (the twin project of industrialisation and agricultural collectivisation) that made the Soviet Union a global superpower; no matter that he lived in the Kremlin, of all places-he had not seen through the theological studies for which she had worked so hard. As Svetlana Allilueva, Stalin's daughter recalled:

She was very devout and dreamt that her son would become a priest. She remained religious until her last days and when father visited her not long before her death she told him: "It's a shame that you didn't become a priest" ... He repeated these words of hers with delight; he liked her scorn for all he had achieved, for the earthly glory, for all the fuss. (Suny 1991, p. 51)

After all, the highest calling in life for a young man was to be a priest in the church.

\section{Transition: From Theology to the Philosophy of Socialism in Power}

Stalin may have left the church but he did not relinquish his interest in matters theological. Indeed, his path from religious faith to Marxism was not the first time this had happened, nor the last. Engels, with his Reformed background and the strong religious commitment of his youth, set the initial example (Boer 2012, pp. 233-72). In the same group, we also find Louis Althusser, Henri Lefebvre, Terry Eagleton and Kim Il Sung, to mention but a few. Crucially, they did not give up their interest in such matters. Even if they had "lost" their faith (and not all did), they maintained a lively interest in, if not an insight into, the realities of belief, theology and the church. So also with Stalin. 
In order to indicate how theological currents both recurred and were transformed in Stalin's thought after his theological study, let me take a different path from analyses that track the near dissolution of the church in light of systematic anti-religious activities from 1917 to 1939 (Shkarovskii 1999, pp. 67-94; Kalkandjieva 2015, pp. 12-64), or indeed those that seek broader theological influences on Bolshevik language and thought processes. The latter group has various emphases, ranging over a background in Russian Orthodoxy; traditions of Russian "messianism", of which the Bolsheviks were but one example; homologies with theology based on apparent likenesses; the linguistic practices of the Bolsheviks that evince selective similarities with theology; and a process of "secularising" of theology in Bolshevik ideology (Fülöp-Miller 1926; Berdiaev 1934, 1937; Sarkisyanz 1955; Agursky 1987; Halfin 1999; Kharkhordin 1999; Duncan 2000). Notably, none of these works deal with Stalin's texts in any detail, apart from (Vaiskopf 2002, pp. 199-290), who overdoes a few moments in order to reveal the mechanisms of a "tyrannical" mind.

While some of the material mentioned above has indeed been helpful (especially Kharkhordin), my interest is somewhat different: I am interested specifically in Stalin's thought in a more substantial and even constructive way. In doing so, I summarise three pertinent points of a recent book (Boer 2017b). ${ }^{6}$ Here we find that Stalin's efforts to develop novel analyses of Marxism in light of distinctly new circumstances often engaged with theological categories. To begin with, Stalin's texts are sprinkled with biblical allusions, invocations and inflections-beyond what one would expect from a broader cultural background. These biblical references cover the full canonical range of the Bible, from creation to apocalypse (I return to two crucial biblical texts in the 1936 constitution below). Further, this biblical engagement raises a crucial feature of any tradition in which the founders' texts are central: a scriptural dynamic (where 'scripture' simply designates writings). Thus, interpretation and reinterpretation become the means for developing new directions. But how? The dynamic is itself biblical, turning on tensions between spirit and letter (2 Corinthians 3:6), faithfulness and betrayal, with everyone keen to claim the faithfulness of their own interpretation and the misguidedness of others.

Second is the unexpectedly creative role of what may be called the "delay of communism", analogous to but not necessarily derived from the Christian "delay of the Parousia", or Christ's return. In both cases, the delay turned what was initially regarded as an interim period into the norm, with consequent developments in thought. While the Christian version produced theology itself and the church, the analogous version in the Soviet Union produced a range of important innovations. These include the distinction between socialism and communism, with socialism itself becoming a distinct period. While the distinction itself stems from Lenin, Stalin deployed a number of biblical texts (2 Thessalonians 3:10 and Acts 4:32 and 35) to define it further, especially in the 1936 constitution (see below). Further features arose from the "delay of communism", such as Stalin's approach to linguistic diversity. In contrast to the communist approach to the "language of Paradise" (Genesis 2 and 11), in which the unity of language was not of the past but of the anticipated communist future, Stalin developed - if one considers the full range of his texts on language- $a$ "Pentecostal" (Acts 2) approach. Thus, the greater the totalising unity, the greater the linguistic diversity produced; the more diversity arises, the more does a new form of unity arise. One further example, which concerns what may be called a "proleptic communism" (analogous to proleptic eschatology), in which a future communism becomes creatively present, influencing the structure of the present although it was still to be achieved.

A third feature of the continuing theological structures of Stalin's thought, albeit reshaped in light of the Marxist tradition, concerns nothing less than Marxist anthropology (the doctrine of human nature). The key is an "Augustinian irruption" into both Russian Orthodox assumptions concerning sin

6 I am able to summarise only the main points here. The careful and patient exegesis of Stalin's texts from which these points arise may be found in the book. 
and redemption and Marxist tendencies to a Pelagian focus on good works. To explain: while Russian Orthodoxy assumed that sin entailed a deformation or distortion of human nature, which could be restored through synergeia and while Pelagius argued in his fourth-century debates with Augustine for the ability of human beings to do good works, Augustine stressed the reality and depth of sin and evil, so much so that human beings could not undertake any good works on their own. Marxists until Stalin took a mostly Pelagian line, assuming the inherent good of human beings once released from structures of exploitation and oppression. How does Stalin respond, especially in the moments of reflection during the tumultuous and highly creative 1930s? Human beings have hitherto unrealised potential for immense good but also for evil never seen before. The emphasis on evil appears through the practice of criticism and self-criticism, the deployment of the terminology of $\sin$ (grekh and sogreshit') and above all in the purges, eliminating the kulaks as a class and the "Red Terror". Crucially, the texts move from the easier identification of evil as an external reality to internal evil, at both collective and individual levels. But this is only one side of the development of Marxist anthropology. The other is an intensification of the possibility of good: here Stakhanovism, with its emulation, tempo and grit, provided the first glimpse of a new human nature which both realised the latency of workers and peasants and marked a new departure, let alone the "affirmative action" program with minority nationalities, or indeed the development of a "domestic state", in which wholesale family and childcare became state concerns (and we must remember that Christianity too is not concerned with an eternal human nature but with its transformation). In other words, the development of Marxist anthropology was not merely an Augustinian irruption, with a profound awareness of the intensity and depth of evil, but rather an intensification of both good and evil. Running through Stalin's thought is the profound sense that inherent goodness and the depth of evil should not be separated. They are necessarily connected; without one, the other could not exist.

Let me be clear: I am not suggesting that Stalin was a Marxist with theology at the forefront of his mind. Not at all, for he was seeking ways to develop his primary focus on Marxism in light of new circumstances. But as he did so, theological structures were reshaped in novel ways, which one would expect given the complex relationship between Marxism and theology in Europe and indeed Russia, let alone Stalin's own theological education. The theological resonances I have summarised may have been subtle and subterranean in some cases, requiring a theological ear to discern them but at other times they were overt. Important for my argument in what follows is that these themes were emerging precisely during the lead-up in the 1930s to the rapprochement between state and church in the Soviet Union.

\section{Sergei and Stalin}

With the context outlined above in mind, I now turn to events that would result in the concordat of 1943. At this point, the account concerns the acts and statements of both Sergei (Ivan Nikolaevich Stragorodskiī) and Stalin.

\subsection{The 1927 Declaration and a Theological Contradiction}

The first important date in the process itself is 29 July 1927, when Sergei-who was then Metropolitan of Nizhni Novgorod-penned a declaration, which was signed by members of the Provisional Holy Synod. ${ }^{7}$ In it, he was careful to indicate a continuation with the desire of Patriarch Tikhon 8 "to place our Russian Orthodox Church in the correct relationship [pravil'nye otnosheniia]

7 The full text of the declaration may be found in a number of sources. An English translation may be found at http://www.rocorstudies.org/2017/06/09/3098, with the Russian version in (Odintsov 1994a, pp. 131-33), also at http://www.gumer.info/bogoslov_Buks/ortodox/Article/Dekl_Ser.php.

8 Tikhon had already been emphasising (1919, 1923 and 1925), in more guarded fashion, the expectation that believers should be loyal to the state insofar as this did not undermine one's loyalty to God. The authenticity of the 1925 statement has at times been called into question (Kalkandjieva 2015, p. 22). 
with the Soviet government and in this way to provide the Church with a chance for a perfectly legitimate and peaceful existence". This desire had to overcome a "natural and justified distrust of the government" against the church, generated by "foreign enemies of the Soviet state", which included some church leaders and ordinary members of the church itself. Sergei alludes here to actions during the "Civil" War, in which the White Armies were aided and abetted by foreign powers, as well as the subsequent acts of sabotage fostered by the blockade against the Soviet Union. All of this, observes Sergei, creates an atmosphere of "mutual distrust and suspicion of all kinds" and destroys the possibility of a peaceful life. In this light, it is necessary for the church to begin the path of "legal and peaceful existence", showing that "we the Church leaders are not on the side of the enemies of our Soviet state" but "with our people and with our government [ a s nashim narodom is nashim pravitel'stvom]". The first step in such a process was to gain permission for the Holy Synod to meet and manage the activities of the church. This permission was granted, meaning that the church was now canonical and legal. Tellingly, Sergei points out that the church should offer prayers of thanksgiving to God for these developments and to the Soviet government for its attention to the "spiritual needs of the Orthodox population". Let me stress the repeated statements such as "loyal to the Soviet

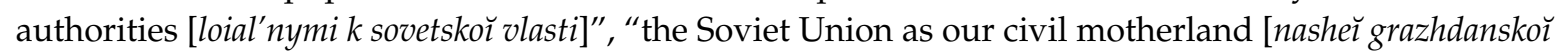
Rodinou]", 9 the need "to establish peaceful relations [mirnye otnosheniia] between the Church and the Soviet government", as well as the need for clergy abroad to cease anti-Soviet rhetoric and actions and to commit to "complete loyalty [polnoŭ loial'nosti] to the Soviet government in all of its social activities" or suffer expulsion from the ranks of the clergy.

Needless to say, this was a somewhat controversial document (Odintsov 1992), with a good number dissenting, whether church leaders abroad (who had fled Russia after 1917) or in prison-although many also reconciled later. But this document makes quite clear that the initiative for engagement with the Soviet government was as much, if not more, an act coming from within the church. Sergei was fully aware that the church was losing and indeed had lost-due to the systematic and highly effective anti-religious campaigns-its jurisdiction not only over Russia but especially abroad. Whether they had fled after 1917 or whether they had been long in other countries, alternative Orthodox organisations from the Balkans to the Americas had been established with an explicitly anti-Soviet and anti-communist agenda (Kalkandjieva 2015, pp. 12-64). However, the document also reveals implicitly that the Russian church itself was riven with tensions. These were not merely the result of the October Revolution and the anti-religious drive of the new government, under which many churches had been closed, with priests and bishops who opposed the government imprisoned and executed and church members excluded from many jobs. The turmoil in the church goes further back.

In order to understand these tensions from a theological perspective, let me return to the text of Sergei's proclamation. He quotes two biblical texts, from Romans 13:5 and 1 Timothy 2:2:

While remaining Orthodox, we remember our duty to be citizens of the Union "not only out of fear but also for conscience' sake", as the Apostle teaches us (Romans XIII, 5). And we hope that with God's help and with our common cooperation and support we shall achieve this task...

It is for a very good reason that the Apostle admonishes us that in order "to quietly and peacefully live" in all godliness, we can either obey the legitimate authority (I Tim. II, 2) or withdraw from society. None but armchair dreamers can think that such a vast institution as our Orthodox Church with its entire structure organization can exist peacefully in a country while walling itself off from the authorities.

9 Rodina evinces rich connotations of home, family, household, birthplace and homeland. Crucially, Sergei speaks of the Soviet Union being such a "motherland", rather than Russia. Stalin was to use the term "Soviet motherland" extensively in the 1940s (Stalin 1984, p. 34; Stalin 1997, p. 143; Stalin 1986, p. 19; Stalin 1997, p. 212; Stalin 1986, p. 33; Stalin 1997, p. 220; Stalin 1986, p. 58; Stalin 1997, p. 233; Stalin 1986, p. 89; Stalin 1997, p. 36). See also the poem, "Rodina", dedicated to Stalin by Bishop Demitrius (Gradusov) in 1943 (Vasil'eva et al. 2009, pp. 83-84). 
The first is from a longer biblical text that begins with "Let every person be subject to the governing authorities; for there is no authority except from God and those authorities that exist have been instituted by God" (Romans 13:1). While the verses that follow exhibit signs of a tension, in which the earthly authorities are subject to and must follow divine authority (Elliott 1997), the text has been deployed time and again to justify the church's engagement with and support of earthly governance. The longer context for the quotation from 1 Timothy evinces a similar tone: "First of all, then, I urge that supplications, prayers, intercessions and thanksgivings be made for everyone, for kings and all who are in high positions, so that we may lead a quiet and peaceable life in all godliness and dignity" (vv. 1-2). ${ }^{10}$ So far, so good, but Sergei emphasises one side of a profound contradiction at the very heart of Christian thought: support for the powers that be runs up against a profound challenge to the status quo. Thus, on the other side we find that if the authorities do not follow God's law, then a divine agent is ready to topple their power-ranging all the way from Moses and the ungodly rule of Pharaoh to Esther and Mordecai in response to the oppression of Haman, if not Cyrus, king of the Medes and Persians, who is God's "messiah" (Isaiah 45:1) for punishing the wayward Israelites. This tension or contradiction runs through the various branches of the Christian tradition (Boer 2014, pp. 125-206), although its relevance here relates to the Russian context. Given the complexity of events, the two sides of the contradiction constantly shift their approach — to invoke (Mao 1965)—with one side gaining importance and then the other. Before 1917, the mainstream Russian Orthodox Church was solidly enmeshed with the tsarist autocracy, while more radical and reform minded currents were opposed. After 1917, the relationship shifted, with the church hierarchy at odds with the new government, while reform groups sought to work with it in various ways in order to change the church itself.

In a little more detail: already in the later nineteenth century, the church was riven with movements for reform. The close integration with the church and the autocracy, which was itself not without difficulties (witness the effects of Peter I's suspension of the patriarchate), was seen by more and more as stifling and potentially harmful (Shevzov 2004). That the autocracy itself was wavering and crumbling obviously assisted matters. By the time of the revolutions in 1905 and 1917, the variety of reform movements had become even stronger, emerging as a loose alliance known as Renovationism (Levitin-Krasnov 1993; Roslov 2002). This was not one movement but the coalescence of many, including but not limited to The Living Church (Zhivaia tserkov'), the Union for the Renewal of the Church (Soiuz tserkovnogo vozrozhdeniia) and the Union of the Communities of the Ancient Apostolic Church (Soiuz obshchin drevneapostol'skor tserkvi). The leader of this final group was Aleksandr Vvedenskii, Metropolitan of Moscow, who was later to become synonymous with Renovationism. Indeed, the movement only ended with his death in 1946. Each group had its own emphases, ranging from liturgical reform through changes to rules concerning marriage for clergy to a distinct Christian communist tradition that went back to the early church of Acts 2 and 4 (Boer 2018). Already, the more overtly socialist of the clergy had formed in St Petersburg, in May 1917, the Union of the Democratic Clergy and Laity, which would feed into the wider Renovationist movement. But this emphasis was by no means a new development with Eastern Orthodoxy, for one may argue that certain elements of this Christian communist tradition had become part of the very structures of Eastern Orthodoxy, with its distinct emphases on collective religious experience and community (sobernost), as well as the possibility for experiencing the salvific reality of union with God already in the context of collective worship (Prosic 2015, 2017). As for Renovationism, its official beginning was the seizure in May 1922 of the patriarchal offices-while Tikhon was under house arrest—by reformist leaders and clergy and the establishment of the "Higher Church Authority". Soon a major Moscow Council was held in April-May of 1923, by which time the Renovationists controlled much church property and had opened two theological colleges. Perhaps it peaked too

10 Other texts would also have been at Sergei's disposal, such as Titus 3:1, with its emphasis on obeying the powers, principalities and magistrates, and 1 Peter 2:13 concerning submission to kings and governors. 
early, perhaps its active support of the Soviet government was too rapid, perhaps its involvement with the NKVD was unwise, perhaps it was unable to overcome its internal differences and struggles and perhaps it did not contend with the resilience of the rest of the church. Renovationism faltered, split and became a minority movement on the sidelines. Its demise was ensured after the 1943 concordat with Stalin, when the government and the new patriarch worked to close down the last remnants (Vasil'eva et al. 2009, pp. 332-35; Chumachenko 2002, pp. 37-39).

Crucial for my purposes is the fact that none other than Sergei was for a time a member-indeed part of the Higher Church Authority — of the Renovationist movement in the early 1920s. He was soon to reconcile with the main church when Patriarch Tikhon returned to active duty but not before he had seen the importance of working towards a rapprochement with the new government-hence his declaration from 1927. In light of my earlier observations concerning this profound contradiction at the heart of Christian theology, Sergei may be seen to have embodied one or the other side of the contradiction in changing circumstances. Yet, the path to a more substantial church-state agreement was a rocky one, not least because the arrests and imprisonments of clergy continued, as well as the closing of churches. However, by the 1930s a new constitution was in the works, so now I turn to Stalin's engagement in the process of rapprochement.

\subsection{The 1936 Constitution and the Church's Response}

The constitution of 1936 — often called the "Stalin constitution" —arose within the wider context of Stalin's thought, which I have summarised earlier, but it requires further attention due to the implications for church-state relations. Two features stand out, one indirect and the other direct. The first concerns article 12 of the constitution:

In the U.S.S.R. work is a duty and a matter of honour for every able-bodied citizen, in accordance with the principle: "He who does not work, neither shall he eat [kto ne rabotaet, tot ne est]".

The principle applied in the U.S.S.R. is that of socialism: "From each according to his ability, to each according to his work [ot kazhdogo po ego sposobnosti, kazhdomu-po ego trudu]". (Stalin 1978, article 12; Stalin 2015, stat'ia 12)

Both quotations are glosses on biblical texts, one from 2 Thessalonians 3:10 and the other from Acts 4:32 and 35 (mediated via the communist tradition). At first sight, they may seem innocent enough, useful pegs perhaps on which to hang communist slogans. But their appearance in the constitution entailed a significant process of creative exegesis. ${ }^{11}$ Thus, "anyone unwilling to work should not eat" became the hermeneutical frame through which the text from Acts 4, "everything they owned was held in common ... They laid it at the apostles' feet and it was distributed to each as any had need", was reinterpreted. Already in 1917, 2 Thessalonians 3:10 had been used by Lenin to define what would soon be called socialism, in distinction from communism (the distinction was a Bolshevik innovation). Stalin would make much greater use of the text, extending the sense of those not working - the idle capitalists and bourgeoisie - to those who lagged behind in the project of creating socialism. Further, it became the interpretive key for reworking the communist slogan, "from each according to ability, to each according to need" (a gloss on Acts 4) into a slogan for socialism, "from each according to ability, to each according to work". These two forms of the slogan became the means to distinguish socialism from communism. By the time the texts they appeared in the 1936 constitution, they had undergone-already from 16 years earlier (Stalin 1953, p. 420; Stalin 1947, p. 405)—a notable process reinterpretation in Stalin's hands. And he was not content to let such matters rest in 1936, for he

11 For a detailed study of process of this reinterpretation, with careful attention to the texts of Lenin and Stalin, see Boer (2017a). 
would continue to refer to these texts in the lengthy study of economic problems under socialism many years later (Stalin 1986, pp. 272, 275; Stalin 1997, pp. 202, 205).

While article 12 with its biblical texts was indirect, a gesture perhaps towards the church and believers, article 124 was quite direct: "In order to ensure to citizens freedom of conscience, the church in the U.S.S.R. is separated from the state, and the school from the church. Freedom of religious worship and freedom of anti-religious propaganda is recognized for all citizens" (Stalin 1978, article 124; Stalin 2015, stat'ia 124). The separation of the church from the state and education was long-standing policy, so the crucial phrase concerns "freedom of religious worship" alongside the freedom for anti-religious agitation. Compared with the constitution of 1918, this was a considerable step. ${ }^{12}$ However, Stalin had to insist on this article against significant opposition, which emerges in debates around the constitution. For example, one amendment proposed a provision for the prohibition of religious rites, which Stalin rejects as "running counter to the spirit [ne sootvetstvuiushchuiu dukhu]" of the constitution (Stalin 1978, p. 192; Stalin 1997, p. 145). Another amendment related to article 135, which stated that all citizens of the U.S.S.R., "irrespective of race or nationality, religion, educational and residential qualifications, social origin, property status or past activities" should be eligible to vote in elections and be elected as deputies. The amendment suggested that "ministers of religion, former Whiteguards, all the former rich, and persons not engaged in socially useful occupations" should be disenfranchised, or at least restricted to participating in elections but not be eligible to be elected. Stalin-with some humour-opposes the amendment on the grounds that earlier disenfranchisement was always meant to be temporary and restorative. When such people had come around, through education and rehabilitation, to become useful parts of the new society, they would be restored to full rights. Given the successes of the "socialist offensive" of the 1930s, with the obliteration of the power of the old ruling class and the strength of the new system, such people should be allowed and enabled to become full participants in elections (Stalin 1978, pp. 192-93; Stalin 1997, p. 145).

The signal to the church was clear and it acted, under Sergei's guidance. The church hierarchy, as well as many local churches, began to petition for the re-opening of places of worship and monasteries, for the celebration of religious rites and festivals, for religious personnel to be eligible for a wide range of employment in collective farms and rural soviets from which they had earlier been barred and for religious candidates in the legislative elections (Davies 1997, p. 80; Fitzpatrick 2000, p. 179). Preachers took the opportunity to emphasise Stalin's knowledge of theology and the Bible. One observed: "Stalin, working out the Constitution, took most of the statements from the gospels because the principle 'He who does not work shall not eat' (article 12) is similar to that of the gospels". Or as a Baptist pastor in Leningrad stated: "Stalin —we respect him, because he was put in place by the Lord God"—as indeed Sergei had already observed in 1927. Further, many worshippers at the 1937 Easter service at lzmailovo-Troitskii cathedral wore official badges, some of which had portraits of Stalin (Davies 1997, pp. 78-79; see also Siegelbaum and Sokolov 2000, pp. 184-90). While the sources I have cited for this material tend to see it as opportunism on the part of religious leaders and laypeople, I suggest that they actually express in their own way a truth concerning Stalin's awareness of the theological and ecclesiastical issues at stake.

Nonetheless, it was not smooth sailing from the constitution to the concordat of 1943. Many in the government were loath to give up the anti-religious activities of the earlier decade and opposition to the government continued on the part of some religious leaders. But the trend was moving in the direction stipulated by the constitution. For example, by the late 1930s the League of the Militant Godless began to wind down, with its publications ceasing by 1941 and its complete disbandment soon afterwards. The crucial turning point was the outbreak of the Second World War and the invasion of the Soviet Union by Hitler's Wehrmacht in 1941. Sergei was quick to act, publishing on the first day

12 The relevant article from the 1918 constitution of the RFSSR reads: "For the purpose of securing to the workers real freedom of conscience, the church is to be separated from the state and the school from the church and the right of religious and anti-religious propaganda is accorded to every citizen" (1918a, article 13; 1918b, stat'ia 13). The 1924 constitution does not contain an article concerning religion. 
(22 June 1941) of the invasion a statement that invoked the glorious history of heroes who had saved the country in the past before observing:

Our Orthodox Church has always shared the destiny of her people. Together with them she has suffered in times of trouble and has been consoled by their success. Nor will she abandon her people now. She gives heavenly blessing to their forthcoming heroic deeds. (Kalkandjieva 2015, p. 94; Vasil'eva et al. 2009, p. 39)

Apart from invoking the theme of holy war, the document-which appeared on the high holy day celebrating Russian saints-actively countered western Orthodox leaders who welcomed Hitler's invasion as a punishment against "godless communism". The "fascist bandits", Sergei observed, knew "no law but naked force" and they were accustomed to "ridicule the highest postulates of honour and morality".

\subsection{The 1943 Concordat}

This was followed by a plethora of moves by the church and the government, indicating implicit and increasingly explicit cooperation. The church was certainly busy, issuing no less than 33 major statements and sermons between the time of Hitler's invasion to Sergei's election as patriarch. ${ }^{13}$ The documents were produced by a number of church leaders, with Sergei, as patriarchal locum tenens, setting the agenda and three others (Exarch Nikolai of Ukraine, Metropolitan Aleksii of Leningrad and Archbishop Andrei of Saratov) focusing on more specific and local issues. The overall aim was to call the Orthodox faithful within the Soviet Union to rally in defence of the "Motherland", to assert Moscow's jurisdiction over lands to the west that had entertained separating from Moscow, ${ }^{14}$ to celebrate-as the Red Army moved westward-victories at the front and to appeal to all Christian believers in the world to support the war effort. Sergei also gave a number of interviews for domestic and international audiences concerning religious freedom in the Soviet Union (Boobbyer 2000, pp. 171-72), while the church raised a not inconsiderable amount for the war effort, more than 300 million roubles, even creating a tank column supported by the church (Vasil'eva et al. 2009, pp. 60-61, 96-98). For its part, the government-with an eye on the domestic situation and the international needs of the war effort-promoted its 1936 constitution, pointing out that freedom of religion was now law in order to counter international anti-communist criticism. ${ }^{15}$ Many acts followed: the celebration of Easter in 1942 was fully sanctioned; the government stressed the role of Orthodox Christianity in Russian history and culture; it appointed clerics to state commissions, such as Metropolitan Nikolai of Kiev and Galicia, who became part of the Extraordinary State Commission for the Investigation of Nazi Villainies. Further, the Soviet government actively enhanced the claim that Sergei was the only legitimate successor of patriarch Tikhon, aligning his name with the Russian Orthodox Church and thereby bolstering Moscow's claim to legitimate jurisdiction and canonical authority over all dioceses that belonged to the church before 1917, if not beyond. ${ }^{16}$

By now it should be obvious that the meeting between Stalin and three hierarchs in September of 1943 was far from fortuitous, if not overdue. It had a long history of preparation from both

13 While (Vasil'eva 1999, p. 44) estimates more than 20 statements (see her analysis on pp. 44-104), (Kalkandjieva 2015, p. 95) identifies 33. See further the table and subsequent analysis in the latter's work (Kalkandjieva 2015, pp. 95-113). Since a good number of studies have covered the church's acts in some detail, I summarise the main points here Odintsov and Kochetova 2014).

14 Actively fostered by the German and Romanian occupying forces before they were driven back, albeit with different emphases. While the Germans attempted to encourage divisions within the Orthodox churches in Ukraine, Belarus and the Baltic states, the Romanians in Transnistria through to Odessa sought to assert the control of the patriarch of Bucharest.

15 While these moves are at times cast in terms of responses to international capitalist pressure (Kalkandjieva 2015, pp. 150-51), my approach is to see them in light of internal dynamics.

16 An important role was also played by two volumes, containing material by Russian church leaders and actively distributed internationally by the government: The Truth about Religion in Russia (1942), which also appeared in English translation ( 1944); The Russian Orthodox Church and the Great Patriotic War (1943). Stalin certainly knew what was at stake and Sergei appreciated the efforts: they exchanged telegrams on the Orthodox Christmas of 5 January 1943. 
sides. Apart from Stalin's awareness of the church's inner workings, in terms of thought, culture and structures, and apart from provisions in the 1936 constitution, his and the government's actions in the early 1940s in domestic and international arenas played a significant role. Indeed, earlier on the same day of the meeting he had proposed establishing the Council for the Affairs of the Russian Orthodox Church. On the church's part, its efforts at recalibrating and recovering-in a very different context—its canonical jurisdiction and administrative authority were finally bearing fruit. What happened at the meeting, which took place soon after Sergei's return to Moscow from Ulianovsk? The key documents are available and have been studied in some detail by others, so I do not seek to repeat their efforts here (Odintsov 1994b, pp. 282-90; Vasil'eva et al. 2009, pp. 194-203; Pospielovsky 1997, pp. 141-42; Roccucci 2011; Kalkandjieva 2015, pp. 180-83). However, I do want to emphasise Stalin's role, at least as it was reported by Karpov the day after the meeting.

While the invitation to meet came from Stalin and while he thanked them for support during the war and indicated that the issue of the patriarchate could be discussed, he initially responded to requests from Sergei and the two hierarchs Nikolai and Aleksii (who was to become patriarch after Sergei). These included the most urgent request from Sergei: election of a patriarch. Stalin replied by asking what the title would be, to which Sergei indicated his agreement to an earlier discussion. Instead of "Patriarch of Moscow and all Rossiia" (Tikhon's earlier title), it would be "Patriarch of Moscow and all Rus'". This entailed an astute claim to all peoples and churches that stemmed from the ancient Kievan Rus', from which Great Russians, Ukrainians and White Russians had descended. As for arrangements, Sergei indicated it would take a month to organise a sobor, at which point Stalin smiled and asked whether it was possible to apply "Bolshevik tempo [bol'shevistskie tempy],"17 with all resources made available for a meeting as soon as possible. They agreed on 8 September. The implications were immense. Apart from the brief tenure of Tikhon (1917-1925), the patriarchate had been vacant since Peter I refused to approve an appointment in 1700. Once a new patriarch was in place, it would entail a restoration of the central church administration and thereby a host of other church activities.

With the most important item agreed upon, they dealt with the need for theological education (recall Stalin's own earlier experience). At the requests of Sergei and Aleksii, Stalin said that he did not object to the opening of theological colleges and academies. Further requests from all three included a monthly journal, the opening of new churches in areas where few existed, release of bishops from prison, rights of free movement for clergy, financial reorganisation of the church and even candle production. Stalin replied that he had no objection, asked for a list of imprisoned bishops and said he would study the issue of free movement. By now-especially when we come to the question of candles-it is clear that the discussion was open and covered a significant range of issues. At this point, Stalin once again took the initiative, raising the question of state support for the church. Earlier, he had offered financial support for the sobor, which Sergei initially refused. By this time, Sergei and the others were more open. Observing that the living conditions of the clergy were poor, with no transport, Stalin suggested state subsidies, food at discounted government prices, the provision of cars with fuel and - most importantly—new premises for the patriarchate. He proposed the former residence of the German ambassador, which would be completely refurbished at the state's expense. All this support could hardly be refused but Stalin repeatedly asked if they had any further needs. Finally, he informed them of the Council for the Affairs of the Russian Orthodox Church, through which formal channel all church affairs would now be managed. ${ }^{18}$ Crucially, Karpov reports that Stalin turned to him as head

17 Here I follow Odintsov's version of the text (Odintsov 1994b, p. 285), which has tempy rather than temny (Vasil'eva et al. 2009, p. 197). The latter is clearly a typographical error (н instead of $\Pi$, especially in light of Stalin's common use of bol'shevistskie tempy elsewhere (Stalin 1954, p. 75; Stalin 1951, p. 73; Stalin 1954, p. 142; Stalin 1951, p. 140), if not bol'shevistskikh tempov (Stalin 1954, p. 235; Stalin 1949, p. 229).

18 The tendency to see CAROC as a manifestation of state surveillance and control misses the fact that such institutional structures are necessary for formalising church-state relations-as happens in many contexts. This requires a delicate balance of the state's and the church's interests. The guidelines for CAROC may be summed up as follows: "establishing 
of the new body and said: "Don't forget, however, that you are not the church's chief procurator and in your activities you must emphasise the independence of the church" (Pospielovsky 1997, p. 142; Odintsov 1994b, p. 289; Vasil'eva et al. 2009, p. 202). Stalin took a close interest in the later workings of the church and CAROC (Vasil'eva et al. 2009, pp. 249-51, 262-63, 268-69, 271, 291-92, 296-97, 354-57, 363-69, 402-5, 411-12, 474-75, 508-12; Odintsov 1994a), continuing to forbid the latter's intervention in the church's administration, canonical matters and doctrine (Kalkandjieva 2015, p. 184). The meeting itself, running to almost two o'clock the next morning, concluded with the drafting of a press release. By now, I hardly need to point out how much of an informed role Stalin played.

Three days later the sobor met in Moscow, with 19 bishops present. ${ }^{19}$ Sergei was elected patriarch under the new title, the Holy Synod was re-established and a number of statements were issued, condemning Hitlerism and all who would collaborate with Fascism (in line with the string of pronouncements from 1941 onwards) and a word of thanks addressed to the government. Let me quote the latter:

Deeply moved by the sympathetic attitude of our national Leader and Head of the Soviet Government, J. V. STALIN, toward the needs of the Russian Orthodox Church and toward our modest works, we, his humble servants, express to the Government our council's sincere gratitude and joyful conviction that, encouraged by this sympathy, we will redouble our share of work in the nationwide struggle for the salvation of the motherland.

Let the Heavenly Head of the Church bless the works of the Government with the Creator's blessing and let him crown our struggle in a just cause with the victory we long for and the liberation of suffering humanity from the dark bondage of fascism.

(Signed by Sergei, Metropolitan of Moscow and Kolomna and eighteen other metropolitans, archbishops and bishops). (Daniels 1993, pp. 228-29; Vasil'eva et al. 2009, pp. 67-68)

This word of thanks was given not merely for the council and the restoration of the patriarchate but also for the increasing cooperation of the previous years. Sergei may not have lasted long as patriarch, dying in May of 1944 (and replaced by Aleksii). But the effect was to consolidate the revival of the Russian Orthodox Church. With the patriarchate finally back in action, central church administration was restored, a church periodical began to be published, a theological academy (Moscow Theological Academy) and three colleges were re-opened, monasteries and thousands of churches began to function-albeit not without local resistance and struggle (Chumachenko 2002, pp. 57-67). By the time of Stalin's death a decade later, the number of functioning churches had expanded from a few hundred to over 20,000, while the church actively pursued the reintegration of its international parts back into its structure. Throughout the whole process, regular updates were provided to Stalin by Sergei and then Aleksii (for example, see (Vasil'eva et al. 2009, pp. 80-81, 177-78)). The effect of the concordat of 1943 was not merely to restore to some extent the jurisdiction of the Moscow patriarchate, for it went well beyond its earlier state. At the Moscow Pan-Orthodox Conference of July 1948, its influence stretched even further than during imperial times, although it also marked the consolidation of Cold War differences between Orthodox churches in communist countries under the jurisdiction of Moscow and those in capitalist countries under Constantinople. Only with Khrushchev from the beginning of the 1960s was systematic persecution reinstated (Chumachenko 2002, pp. 143-88), producing a decline that carried on under Brezhnev. However, it could be argued that the church's recovery under Stalin enabled it to withstand the later storm, so as to emerge after 1991 with its basic structures in place.

relationships with diocesan hierarchs and archpriests, registration of clergy ... considering applications from among the faithful for the opening and/or closing of churches ..., accounting and registration of all functioning and non-functioning Orthodox churches and chapels, informing the Council on the activities of religious associations and informing local law enforcement agencies about religious groups and for execution of and control over the execution of decisions taken by the Council" (Odintsov 1995, pp. 86-87). See also the detailed study by Odintsov and Chumachenko (2013).

19 See also the report provided by V. N. Merkulov to Stalin concerning the gathering (Vasil'eva et al. 2009, pp. 227-30). 


\section{Conclusions}

I have sought to emphasise the theological and ecclesiological factors in the rapprochement between the church and Soviet government, between Sergei and Stalin—factors that were important from both sides. Of course, each side had its own agenda in light of changing and often dire circumstances. If the church was certainly not a "pawn on Stalin's chessboard" (Kalkandjieva 2015, p. 180), then neither was Stalin a tool of the church's own efforts at re-establishing and extending its jurisdiction and authority. The subsequent international effort during the Cold War to challenge and replace the impression of widespread persecution of the church is beyond my remit here, although those who given this phase detailed attention note its difficulties and failures but also considerable success, not least because of internal dynamics within foreign churches (Shkarovskii 1999, pp. 284-331; Miner 2003, pp. 205-314; Kalkandjieva 2015, pp. 207-344).

I close on a slightly different note, returning to Stalin. In light of these developments and especially a role for Stalin somewhat greater than is often acknowledged, we should not be surprised that Sergei, Aleksii and other leaders often referred to Stalin as "deeply revered [glubokochtimyil]" and "beloved by all [vsemi liubimyl]", as a "wise, divinely appointed leader [mudromu, bogopostavlennomu Vozhdiu]", who had become so through "God's Providence [Promysel Bozhiv]" (Vasil'eva et al. 2009, pp. 76, 109, 177, 169). Indeed, they express feelings of "deep love and gratitude [glubokoľ $k$ Vam liubvi i Blagodarnosti]" for his "constant, wise attention to Her [the Church's] needs [postoiannoe mudroe vnimanie k Eia nuzhdam]" (Vasil'eva et al. 2009, pp. 109, 178; see further pp. 46, 93-94, 96, 106, 146, 161, 163-65, 167, 172, 177-78, 349-50). Was this nothing more than astute political manoeuvring, on both sides? Or was it something more? We have only the texts and actions from which to piece together a possible picture, including rumours of a "mysterious retreat" undertaken by Stalin in 1941, as the Germans were rolling into the Soviet Union (Radzinsky 1997, pp. 472-73), as also the fact that the Russian Orthodox Church continues periodically to issue calendars bearing Stalin's image.

Conflicts of Interest: The authors declare no conflict of interest.

\section{References}

Agursky, Mikhail. 1987. The Third Rome: National Bolshevism in the USSR. Boulder: Westview.

Anonymous. 1918a. Constitution of the Russian Socialist Federative Soviet Republic. Lewisburg: Bucknell University. Anonymous. 1918b. Konstitutsiia (osnovnoŭ zakon) Rossiŭskoŭ Sotsialisticheskoŭ Federativnoŭ Sovetskoŭ Respubliki Priniata v Vserossiǔskim S"ezdom Sovetov V Zasedanii ot 10 Iiulia 1918 Goda. Leningrad.

Anonymous. 1942. Pravda o Religii v Rossii. Moscow: Moscow Patriarchate.

Anonymous. 1943. Russkaia Pravoslavnaia tserkov' i Velikaia Otechestvennaia Voina. Moscow: Moscow Patriarchate. Anonymous. 1944. The Truth about Religion in Russia. Translated by Ernest Sergeant. London: Hutchinson and Co. Berdiaev, Nikolai. 1934. Wahrheit und Lüge des Kommunismus. Translated by Ives Schor. Lucerne: Vita Nova. Berdiaev, Nikolai. 1937. The Origin of Russian Communism. Translated by R. M. French. London: G. Bles.

Boer, Roland. 2012. Criticism of Earth: On Marx, Engels and Theology. Leiden: Brill.

Boer, Roland. 2014. In the Vale of Tears: On Marxism and Theology V. Leiden and Chicago: Brill and Haymarket.

Boer, Roland. 2017a. Stalin's Biblical Hermeneutics: From 2 Thessalonians 3 to Acts 4 . Journal of the Bible and Its Reception 4: 71-89. [CrossRef]

Boer, Roland. 2017b. Stalin: From Theology to the Philosophy of Socialism in Power. Singapore: Springer.

Boer, Roland. 2018. Red Theology: On the Christian Communist Tradition. Leiden: Bril.

Boobbyer, Philip. 2000. The Stalin Era. London: Routledge.

Chumachenko, Tatiana. 1999. Gosudarstvo, Pravoslavnaia Tserkov,' Veruiushchie, 1941-1961 gg. Moscow: AIRO-XX. Chumachenko, Tatiana. 2002. Church and State in Soviet Russia: Russian Orthodoxy from World War II to the Khrushchev Years. Translated by Edward Roslov. Armonk: M.E. Sharpe.

Daniels, Robert Vincent, ed. 1993. A Documentary History of Communism in Russia: From Lenin to Gorbachev. Burlington: University of Vermont Press.

Davies, Sarah. 1997. Popular Opinion in Stalin's Russia: Terror, Propaganda and Dissent, 1934-1941. Cambridge: Cambridge University Press. 
Dickinson, Anna. 2000. A Marriage of Convenience? Domestic and Foreign Policy Reasons for the 1943 Soviet Church-State Concordat. Religion, State E Society 28: 337-46.

Duncan, Peter. 2000. Russian Messianism: Third Rome, Revolution, Communism and after. London: Routledge.

Dunlop, John. 1983. The Faces of Contemporary Russian Nationalism. Princeton: Princeton University Press.

Elliott, Neil. 1997. Romans 13:1-7 in the Context of Imperial Propaganda. In Paul and Empire: Religion and Power in Roman Imperial Society. Edited by Richard A. Horsley. Harrisburg: Trinity Press International, pp. 184-204.

Fitzpatrick, Sheila. 2000. Everyday Stalinism: Ordinary Life in Extraordinary Times: Soviet Russia in the 1930s. Oxford: Oxford University Press.

Fletcher, William. 1973. Religion in Soviet Foreign Policy, 1945-1970. London: Oxford University Press.

Fülöp-Miller, René. 1926. Geist und Gesicht des Bolschewismus: Darstellung und Kritik des Kulturellen Lebens in Sowjet-Russland. Zurich: Amalthea Verlag.

Halfin, Igal. 1999. From Darkness to Light: Class, Consciousness and Salvation in Revolutionary Russia. Pittsburgh: University of Pittsburgh Press.

Kalkandjieva, Daniela. 2015. The Russian Orthodox Church, 1917-1948: From Decline to Resurrection. London: Routledge.

Kharkhordin, Oleg. 1999. The Collective and the Individual in Russia: A Study of Practices. Berkeley: University of California Press.

Khlevniuk, Oleg. 2015. Stalin: New Biography of a Dictator. Translated by Nora Seligman Favorov. New Haven: Yale University Press.

Kotkin, Stephen. 2014. Stalin: Volume I: Paradoxes of Power, 1878-1928. New York: Penguin.

Kun, Miklós. 2003. Stalin: An Unknown Portrait. Budapest: Central European University Press.

Levitin-Krasnov, Anatolii. 1993. The Russian Orthodox Renovationist Movement and its Russian Historiography During the Soviet Period. In Religious Policy in the Soviet Union. Edited by Sabrina Petra Ramet. Cambridge: Canbridge University Press, pp. 273-91.

Mao, Zedong. 1965. On Contradiction. In Selected Works of Mao Tse-Tung. Beijing: Foreign Languages Press, vol. 1, pp. 311-47. First Published 1937.

Miner, Steven Merritt. 2003. Stalin's Holy War: Religion, Nationalism and Alliance Politics, 1941-1945. Chapel Hill: University of North Carolina Press.

Oboznij, Konstantin. 2017. The Russian Orthodox Church in Pskov and Novgorod during the Stalin Era with Special Focus on the Activities of the Council for Russian Orthodox Church Affairs in the Given Regions. Religious-Philosophical Articles/Reliogiski-Filozofiski Raksti 23: 84-105.

Odintsov, Mikhail. 1992. Deklaratsiia mitropolita Sergiia ot 29 iiulia 1927 g. i bor'ba vokrug nee: Vstupitel'naia stat'ia, kommentarii i publikatsiia dokumentov. Otechestvennaia Istoriia 6: 123-40.

Odintsov, Mikhail. 1994a. Russkaia pravoslavnaia tserkov' stala na pravil'nyı̌ put': Dokladnye zapiski predsedatelia Soveta po delam Russkoŭ pravoslavnoĭ tserkvi pri SNK SSSR G. G. Karpova I. V. Stalinu. 1943-1946 gg. Istoricheskiu Arkhiv 3: 139-48.

Odintsov, Mikhail. 1994b. Russkie Patriarkhi SS veka. Moscow: RAGS.

Odintsov, Mikhail. 1995. Vlast' i Religiia v Gody Voiny. Gosudarstvo I Religioznye Organizatsii v sssr v Gody Velikoi Otechestvennoi Voiny. 1941-1945. Moscow: RAGS.

Odintsov, Mikhail, and Tatiana Chumachenko. 2013. Sovet po Delam Russkoŭ Pravoslavnoŭ Tsekrvi Pri snk (sm) sssr i Moskovskaia Patriarkhiia: Ėpokha Vzaimodeı̌Stviia i Protivostoianiia, 1943-1965 gg. St. Petersburg: Rossiı̌skoe $\mathrm{Ob}^{\prime \prime}$ edinenie Issledovateleŭ Religii.

Odintsov, Mikhail, and Anna Kochetova. 2014. Konfessional'naia Politika v Sovetskom Soiuze v Gody Velikŏ Otechestvennoŭ VoǔNy, 1941-1945 gg. Moscow: Rosspen.

Pospielovsky, Dimitry. 1984. The Russian Church under the Soviet Regime, 1917-1982. Crestwood: St. Vladimirs Seminary Press.

Pospielovsky, Dimitry. 1997. The ‘Best Years' of Stalin's Church Policy (1942-1948) in the Light of Archival Documents. Religion, State E Society 25: 139-62.

Prosic, Tamara. 2015. Cultural Hegemony, Sobornost and the 1917 Russian Revolution. Stasis 3: $204-25$.

Prosic, Tamara. 2017. The 1917 Russian Revolution and Eastern Orthodox Christian Utopianism. Utopian Studies 28: 268-85. [CrossRef]

Radzinsky, Edvard. 1997. Stalin. New York: Anchor Books.

Rancour-Laferriere, Daniel. 1988. The Mind of Stalin: A Psychoanalytic Study. Ann Arbor: Ardis. 
Reese, Roger. 2014. The Russian Orthodox Church and 'Patriotic' Support for the Stalinist Regime during the Great Patriotic War. War and Society 33: 131-53. [CrossRef]

Roccucci, Adriano. 2009. Le Tournant de la Politique Religieuse de Stalin. Cahiers du Monde Russe 50: 671-98. [CrossRef]

Roccucci, Adriano. 2011. Experience of the Russian Orthodox Church during the Soviet Regime. In The Holy Russian Church and Western Christianity. Edited by Giuseppe Alberigo, José Oscar Beozzo and Georgii Ziabilatsev. London: SCM, pp. 49-65.

Roslov, Edward. 2002. Red Priests: Renovationism, Russian Orthodoxy and Revolution. Bloomington: Indiana University Press.

Sarkisyanz, Emanuel. 1955. Russland und der Messianismus des Orients: Sendungsbewusstsein und Politischer Chiliasmus des Ostens. Tübingen: J.C.B. Mohr.

Service, Robert. 2004. Stalin: A Biography. Boston: Harvard University Press.

Shakhireva, Stephanie. 2007. Swaddled Nation: Modern Mother Russia and a Psychohistorical Reassessment of Stalin. Journal of Psychohistory 35: 34-60.

Shevzov, Vera. 2004. Russian Orthodoxy on the Eve of Revolution. Oxford: Oxford University Press.

Shkarovskii, Mikhail. 1999. Russkaia Pravoslavnaia Tserkov' pri Staline i Khrushcheve: Gosudarstvenno-Tserkovnye Otnosheniia v SSSR v 1939-1964 Godakh. Moscow: Krutitskoe Patriarshee Podvor'e.

Siegelbaum, Lewis, and Andrei Sokolov. 2000. Stalinism as a Way of Life: A Narrative in Documents. Translated by Thomas Hoisington and Steven Shabad. New Haven: Yale University Press.

Solzhenitsyn, Aleksandr. 1972. A Lenten Letter to Pimen, Patriarch of All Russia. Minneapolis: Burgess.

Solzhenitsyn, Aleksandr. 1974. Letter to the Soviet Leaders. New York: Harper and Row.

Stalin, Joseph Vissarionovich. 1953. Congress of the Peoples of the Terek Region, November 17, 1920. In Works. Moscow: Foreign Languages Publishing House, vol. 4, pp. 412-20. First Published 1920a.

Stalin, Joseph Vissarionovich. 1947. S"ezd narodov Terskoŭ oblasti 17 noiabria 1920 g. In Sochineniia. Moscow: Gosudarstvennoe Izdatel'stvo Politicheskoi Literatury, vol. 4, pp. 399-407. First Published 1920b.

Stalin, Joseph Vissarionovich. 1954. To the First Graduates of the Industrial Academy. In Works. Moscow: Foreign Languages Publishing House, vol. 12, pp. 235-36. First Published 1930a.

Stalin, Joseph Vissarionovich. 1949. Pervomu vypusku Promakademii. In Sochineniia. Moscow: Gosudarstvennoe Izdatel'stvo Politicheskoi Literatury, vol. 12, pp. 229-30. First Published 1930b.

Stalin, Joseph Vissarionovich. 1954. New Conditions-New Tasks in Economic Construction, Speech Delivered at a Conference of Business Executives, June 23, 1931. In Works. Moscow: Foreign Languages Publishing House, vol. 13, pp. 53-82. First Published 1931a.

Stalin, Joseph Vissarionovich. 1951. Novaia obstanovka-Novye zadachi khoziaĭstvennogo stroitel'stva: Rech' na soveshchanii khoziaǔstvennikov, 23 iiunia 1931 g. In Sochineniia. Moscow: Gosudarstvennoe Izdatel'stvo Politicheskoi Literatury, vol. 13, pp. 51-80. First Published 1931b.

Stalin, Joseph Vissarionovich. 1954. Talk with the German Author Emil Ludwig, December 13, 1931. In Works. Moscow: Foreign Languages Publishing House, vol. 13, pp. 106-25. First Published 1931c.

Stalin, Joseph Vissarionovich. 1951. Beseda s nemetskim pisatelem Ėmilem Liudvigom, 13 dekabria 1931 g. Sochineniia 13: 104-23. First Published 1931d.

Stalin, I.V. 1954. Kuznetsk Iron and Steel Works Project, Kuznetsk. In Works. Moscow: Foreign Languages Publishing House, vol. 13, p. 142. First Published 1932a.

Stalin, Joseph Vissarionovich. 1951. Kuznetsk. Kuznetskstroŭ. In Sochineniia. Moscow: Gosudarstvennoe Izdatel'stvo Politicheskoi Literatury, vol. 13, p. 140. First Published 1932b.

Stalin, Joseph Vissarionovich. 1978. Constitution (Fundamental Law) of the Union of Soviet Socialist Republics, with amendments adopted by the First, Second, Third, Sixth, Seventh and Eighth Sessions of the Supreme Soviet of the U.S.S.R., Kremlin, Moscow, December 5, 1936. In Works. London: Red Star Press, vol. 14, pp. 199-239. First Published 1936a.

Stalin, Joseph Vissarionovich. 2015. Konstitutsiia (Osnovnoŭ Zakon) Soiuza Sovetskikh Sotsialisticheskikh Respublik (Utverzhdena Postanovleniem ChrezvychaǐNogo VIII s"ezda Sovetov Soiuza Sovetskikh Sotsialisticheskikh Respublik ot 5 Dekabria 1936 g.). Moscow: Garant. First Published 1936b.

Stalin, Joseph Vissarionovich. 1978. On the Draft Constitution of the U.S.S.R.: Report delivered at the Extraordinary Eighth Congress of Soviets of the U.S.S.R., November 25, 1936. In Works. London: Red Star Press, vol. 14, pp. 151-97. First Published 1936c. 
Stalin, Joseph Vissarionovich. 1997. O proekte konstitutsii soiuza SSR: Doklad na chrezvychaĭnom VIII vsesoiuznom s"ezde sovetov, 25 noiabria 1936 goda. Sochineniia 14: 119-47. First Published 1936d.

Stalin, Joseph Vissarionovich. 1984. Order of the Day, No. 95, February 23, 1943. Works 15: 34-40. First Published 1943 a.

Stalin, Joseph Vissarionovich. 1997. Prikaz verkhovnogo glavnokomanduiushchego, 23 fevralia 1943 goda, No. 95. Sochineniia 15: 143-48. First Published 1943b.

Stalin, Joseph Vissarionovich. 1986. Order of the Day, No. 5, February 23, 1945. Works 16: 17-19. First Published $1945 a$.

Stalin, Joseph Vissarionovich. 1997. Prikaz verkhovnogo glavnokomanduiushchego, 23 fevralia 1945 goda, No. 5. Sochineniia 15: 210-12. First Published 1945b.

Stalin, Joseph Vissarionovich. 1986. Order of the Day, No. 20, May 1, 1945. Works 16: 31-34. First Published 1945c. Stalin, Joseph Vissarionovich. 1997. Prikaz verkhovnogo glavnokomanduiushchego, 1 maia 1945 goda, No. 20. Sochineniia 15: 218-21. First Published 1945d.

Stalin, Joseph Vissarionovich. 1986. Order of the Day, No. 371, July 22, 1945. Works 16: 58-59. First Published 1945e.

Stalin, Joseph Vissarionovich. 1997. Prikaz verkhovnogo glavnokomanduiushchego po vorskam Krasnoŭ Armii i Voenno-Morskomu Flotu, 22 iiulia 1945 goda, No. 371. Sochineniia 15: 233-34. First Published 1945f.

Stalin, Joseph Vissarionovich. 1986. Order of the Day of the Minister of the Armed Forces of the U.S.S.R. No. 7, May 1, 1946. Works 16: 87-89. First Published 1946a.

Stalin, Joseph Vissarionovich. 1997. Prikaz ministra vooruzhennykh sil Soiuza SSR, 1 maia 1946 goda, No. 7. Sochineniia 16: 34-36. First Published 1946b.

Stalin, Joseph Vissarionovich. 1986. Economic Problems of Socialism in the U.S.S.R. In Works. London: Red Star Press, vol. 16, pp. 222-96. First Published in 1951-1952a.

Stalin, Joseph Vissarionovich. 1997. Ėkonomicheskie problemy sotsializma v SSSR. In Sochineniia. Moscow: Izdatel'stvo "Pisatel"”, vol. 16, pp. 154-223. First Published 1951-1952b.

Suny, Ronald Grigor. 1991. Beyond Psychohistory: The Young Stalin in Georgia. Slavic Review 50: 48-58. [CrossRef] Tucker, Robert. 1973. Stalin as Revolutionary 1879-1929: A Study in History and Personality. New York: Norton.

Vaiskopf, Mikhail. 2002. Pisatel' Stalin. Moscow: Novoe Literaturnoe Obozrenie.

Vasil'eva, Olga. 1999. Russkaia Pravoslavnaia Tserkov' v Politika Sovetskogo Gosudarstva v 1943-1948 gg. Moscow: IRI RAN.

Vasil'eva, Olga, I. I. Kudriavtsev, and L. A. Lykova. 2009. Russkaia Pravoslavnaia Tserkov' v Gody Velikoŭ Otechestvenno Voiny 1941-1945 gg. Moscow: Sbornik dokumentov.

Volkogonov, Dimitri. 1990. Stalin: Triumph and Tragedy. New York: Grove Press.

Walicki, Andrzej. 1995. Marxism and the Leap to the Kingdom of Freedom: The Rise and Fall of the Communist Utopia. Stanford: Stanford University Press.

Walters, Philip. 1986. The Russian Orthodox Church and the Soviet State. The Annals of the American Academy of Political and Social Science 483: 135-45. [CrossRef]

(C) 2018 by the author. Licensee MDPI, Basel, Switzerland. This article is an open access article distributed under the terms and conditions of the Creative Commons Attribution (CC BY) license (http://creativecommons.org/licenses/by/4.0/). 